\title{
Corruption and Administration of Higher Education Institutions in Nigeria
}

\author{
Amini-Philips, Chinyere ${ }^{1, *} \&$ Ogbuagwu, Chukwuma ${ }^{1}$ \\ ${ }^{1}$ Department of Educational Management, Faculty of Education, University of Port-Harcourt, Port Harcourt, Nigeria \\ Correspondence: Department of Educational Management, Faculty of Education, University of Port-Harcourt, Port \\ Harcourt, Nigeria. Tel: 234-802-322-9714. E-mail: drchiap22@gmail.com
}

Received: February 7, 2017

Accepted: February 21, 2017 Online Published: April 4, 2017

doi:10.5430/wjss.v4n2p12

URL: https://doi.org/10.5430/wjss.v4n2p12

\begin{abstract}
Corruption in this paper refers to absurd or deviant disposition of people in institutions of higher learning which violates the ethical standards. The prevalence of corruption in tertiary institutions is viewed to negate the core values of education at this level. Major themes discussed included definition of corruption, corruption in Nigerian society and higher learning institutions, highlighting the various aspects and shapes of corruption in Nigerian higher institutions. Dimensions of corruption identified included students, lecturers, non-academic staff and administrators. The shapes of corruption among students included bribing of lecturers for unmerited grades, cultism, examination malpractice, attacks on lecturers for stopping students from indulging in examination malpractice, fiscal extortion from innocent students by fellow students who form themselves into "lecturers' boys". Forms of corruption among lecturers included demanding huge amount of money, sex from female students for high grade, etc. Among non-teaching staff, the shades of corruption included monetary extortion from students before they see their results, demanding of money from unsuspecting parents in the guise that they are lecturers with a promise to secure admission for their children/wards, they also act as agents for lecturers, receiving money from students for higher grades after examination. At the administrator's level, shades of corruption included misappropriation and misapplication of fund meant for capital projects, offer of admission to undeserving students for a fee while deserving candidates are by-passed, amongst others. Impact of corruption on higher education administration was discussed and means that can be adopted or adapted to curb the menace were suggested.
\end{abstract}

Keywords: corruption, higher education, administration, institutions, Nigeria

\section{Introduction}

The existence of corruption in the countries of the world over is indisputable. In recent times, this malady has assumed a household word in our nation and its prevalence is assuming a worrisome dimension. Corruption is rife in this country and permeates every sector. In our higher institutions, corruption appears to be widespread, where it has manifested in ways and forms that mirror the Nigerian society. Its effect is indeed very corrosive, affecting the fabric of our core values that were known to protect. Corruption does nobody good because it portends danger for the individuals, students, lecturers, parents, government and the society at large.

Generally, the word corruption is used to describe any act that violates generally accepted norms and behaviour of any society. The Oxford Advanced Learner's Dictionary ( $7^{\text {th }}$ edition, p.329) defined corruption as "dishonest or unapproved behaviour, mostly of people in authority". In line with this, Olubunmi (1995:5) viewed corruption "as an illegal behaviour of people who are either in office or public places and use their authority to do wrong things in return for money or favour". These definitions imply that corruption has to do with persons or individual violating ethical behaviours while they occupy an office or position of authority in schools, colleges, universities, governmental institutions, Church, traditional stool in any given society.

Corruption in many of our institutions is increasing by the day, perhaps because of the culture of silence that pervades university campuses and because most times, the misbehaviours are "swept under the carpet". Corruption in many institutions of higher studies ought to be viewed by all concerned as gross misconduct since it negates the nucleus of 
higher education which is intended for quality graduates for the development of the society. It should be viewed as an anathema by well-meaning individuals both within campuses and the society at large, as it affects the quality of graduates produced in our institutions of higher studies negatively by lowering the standards of students and activities undertaken by them.

The necessity to curb corruption in our post secondary institutions stems from the truth that it is indispensable for achieving the goals of post-secondary education in the nation-high level manpower production, developing and inculcating the proper values for the sustenance of individuals and the society, developing the intellectual capability of the people to comprehend and value their internal and external environment, get both visible and intellectual capacity that will help individuals to be independent and productive members of the society, facilitate and foster scholarship and community service (FRN 2004:36). It is against the foregoing background that this paper sought to examine corruption and administration of higher education in Nigeria.

\section{Understanding Corruption}

The Concise Oxford English Dictionary (Words worth Reference) views corruption as putridity, taint, debasement, spoliation, impurity, perversion, bribery, dishonesty, venality, rottenness and immorality. This definition is all-encompassing as it views everything that is evil as corruption. However, the World Bank (2000) sees the term as unjustly using public office for selfish gains, this is seen when officials receive, solicit or extort money or material things. It is also abused when private agents actively connive to offer bribes to circumvent public policies and processes for competitive advantage and profit.

Besides, people also misuse public offices without necessarily taking bribe but when such offices are used for personal profit, nepotism, stealing of government assets or diversion of state resources that are supposed to be used for the execution or completion of projects. IMF (2000) noted that corruption is the misuse of authority, power or trust for personal benefits and is a temptation indulged in not only by public officials, but also by others holding trusted position, by not-for-profit or private enterprises or organisations. This implies that when an individual in authority deviates from carrying out his duties which he swore by oaths of office and allegiance and engages in acts which solely benefit him, he is said to be corrupt. Also, Section 2 of the ICPC Act (2000) defines corruption to include vices like bribery, fraud and other offences that are related. In this definition, bribery is outstanding and refers to the giving or receiving of money or any kind of favour in return or exchange for undue advantage over other people.

The Federal Republic of Nigeria's Constitution in 1999 (with amendments 2011) prohibits bribery, when it stated that "No person shall offer any officer serving the public money, gifts, property or profit of any sort in the cause of the public officer trying to discharge his official duties. Though the Nigerian Constitution puts the definition of corruption succinctly and forbids it, many public officers including the campus community members still indulge in corruption. Corroborating this state of affairs, Olayinka Ayoola (rtd), former Chairman of ICPC opined that the commonest form of the menace in Nigeria used to be bribery, but in recent years it is the embezzlement of funds meant for the public, extortion, misuse of discretion, misuse of public power for selfish gains, conflicting interest, nepotism, favouritism and unapproved financing of political parties. It therefore means that any person, whether in private or public organizations who violates the laid down rules and regulation on how to deal with the customers and colleagues especially by taking unjust advantage of them, by asking for or demanding gratification in kind or cash is corrupt.

\section{Corruption in the Nigerian Society}

In Nigeria corruption is present in all sectors. It is viewed as an inhibitor of socio-economic development which threatens the corporate existence of Nigeria. Corruption in Africa is led by Nigeria as evidenced by so many indices. With a population of nearly 170million people, all facets of its social life manifest corruption. This allusion is made by the Transparency International (TI). In the year 2000, the Transparency International (TI) carried out a survey of 90 countries in the world which included Angola, Cameroon, Cote D'Ivoire, Ghana, Ethiopia, Kenya, Senegal, Zambia, Zimbabwe, Nigeria, Moldova, India and Venezuela; the Corruption Perception Index (CPI) report showed that Nigeria occupies the $90^{\text {th }}$ position, this means that in the year 2000, Nigeria was the most corrupt country in the world, meaning it was the most corrupt country in the world in 2000.

In 2001, the Transparency International surveyed 91 countries in the world; the CPI report showed that Nigeria occupies the $90^{\text {th }}$ position, taking the second position after Bangladesh. In 2002, 102 countries were surveyed by TI; the CPI report showed Nigeria occupying $101^{\text {st }}$ position with regards to Confidence Interval (CI). In 2003, out of the 135 countries of the world surveyed, Nigeria took the second position. In 2004, it ranked $3^{\text {rd }}$ most corrupt nation out of the 
145 countries of the world surveyed. In 2005, Nigeria was found in the $6^{\text {th }}$ most corrupt nation of the world, having surveyed 158 countries.

In 2006, Nigeria was $144^{\text {th }}$ despite all the anti-graft laws in place. 180 countries were surveyed by the TI in 2007; Nigeria ranked $148^{\text {th }}$ position. It was the $32^{\text {nd }}$ most corrupt country in the world that year. In 2011, out of 146 countries surveyed using the Corruption Perception Index, Nigeria was $144^{\text {th }}$ in spite of all the anti-graft laws in place. In 2012, Nigeria ranked $139^{\text {th }}$ out of 176 countries surveyed; this meant that Nigeria was positioned the $37^{\text {th }}$ most corrupt nation of the world (Uzochukwu, 2013). In 2013, Nigeria took the $144^{\text {th }}$ position of the 177 nations surveyed by Transparency International. In 2014, Nigeria ranked $136^{\text {th }}$ out of 174 countries surveyed by the corruption watchdog, -TI (The Transparency International Corruption Perception Index, CPI, 2014).

Transparency International is an international organization that ranks the level of corruption in any country based on survey with the citizens of that particular country (Uzochukwu 2015). This means that Nigeria is not "Clean" in contrast to countries like New Zealand and Denmark that scored 91\% with high Confidence Index (CI). There is therefore corruption everywhere in Nigeria: Corruption in Nigeria's public service, in law execution agencies, banking system, customs service, sports, faith-based organizations, educational system, etc.

\section{Corruption in Institutions of Higher Education in Nigeria}

In recent times, corruption in higher education institutions in Nigeria has permeated every aspect - students, lecturers, non-teaching staff and the administration of the institutions. Corroborating the above assertion, Iyayi (2010) observed that "there is now a crisis of ethical standards of major proportions in our citadels of higher learning". At the student's' level, the evil called cultism is another aspect of corruption, although on a low scale as a result of the stringent punitive measures adopted against cultists. The widespread academic dishonesty among students (undergraduates and graduates) is another form of corruption which has assumed a worrisome dimension. There have been several reports of lecturers who have been physically attacked while some have been assassinated. Many lecturers have lost properties like laptops, money, or other personal effects. These crimes have been traced to students who perpetuate these crimes on unsuspecting lecturers for stopping them from cheating in examinations.

Another aspect or form of corruption displayed by students is bribery - this is the act of giving money or material things to a lecturer to influence him/her to award unmerited scores. This form of corruption is also known as sorting. Torulagha (2013:6) stated that "there is a relationship between corruption and the poor state of academic standards" that exist in Nigerian universities today. Furthermore, he noted that students who are from well-to-do homes do not have to be present at lectures to obtain high grades. Nkang (2012) warned that students should desist from forming themselves into "lecturers' boys" who act as agents to extort money from innocent students for lecturers' use who eventually give them a percentage of the total collection. Furthermore, she emphasized that this action is academic fraud and that when students learn and perfect in the trade, the cycle continues. She therefore suggested that class/course representatives should be those with impeccable character who can influence their mates positively.

For lecturers, corruption exists in several forms: lecturers who handle students' charts compel students to pay money and change scores awarded by course lecturers for the students to graduate with better grades. Another aspect of corruption among lecturers is that course lecturers award unmerited marks to students for money. Yet another case of corruption among lecturers which is prevalent among male lecturers) is sex for high grades: male lecturers harass the female students with demands for sex in return for high grades while the male students pay their way through. Uzochukwu (2015) observed that these are the things that lecturers do that deserve severe punishment". However, he pointed out that it is most painful because most of the female students harassed are married.

Higher institutions' corruption also manifest among the non-teaching staff, when they demand that students should pay money before they can check their results. Many non-teaching staff in tertiary institutions extorts money from students before they can allow students to check their results. Some even go to the extent of requesting students to give them money before they can give them lecturers' phone numbers. Some unsuspecting parents are made to pay money in the guise that they are lecturers and promise to secure admission for their children/wards. Some non-teaching staff also acts as fronts for lecturers to extort money from the learners after examination.

On the part of administrators, corruption manifests in cases of misappropriation and misapplication of money meant for capital projects. Annually, the Federal Government gives grants to all institutions of higher studies through their management agencies for capital projects - National Universities Commission (NUC) for Universities, National Board for Technical Education (NBTE) for Polytechnics, and National Council for Colleges of Education (NCCE) for Colleges of Education. Unfortunately, sometimes such funds are stolen or diverted to other projects or completely 
misappropriated. The result of this as noted by Ololube (2016), is the declining quality of Nigerian higher education. Corruption also manifests in the recruitment of both academic and non-academic staff. Many staffs are employed in institutions of higher studies based on who they know and not on merit, some pay fabulous amounts of money before they are employed. There is also corruption in accreditation of programmes by accrediting bodies. When members of accrediting panels are bribed, criteria are by-passed and reports are written to favour the department or institution. Corruption is also seen in procurement of materials. Often the prices of materials are slugged and the surplus goes into the pocket of the staff. Another aspect of corruption among administrators is that some rich men bribe Admission officers and Head of Departments to secure admission. Those who are supposed to be admitted are by-passed (Uzochukwu 2015). It is significant to mention at this juncture that the policy of carrying capacity (maximum number of students that is allowed in a programme) for each academic session because of facilities on ground must be liable for this corruption form. This is because with large number of students seeking University education, many candidates are ever-ready to manoeuvre, undermine and outwit through bribery other candidates who merited admission.

\section{The Impacts of Corruption on Higher Education}

Corruption in institutions of higher studies negatively affects all aspects: students, teachers, non-academic staff and the administration. Among students, corruption among higher institution stakeholders has negative implication for learning. Many learners in higher institution do not attend lectures because the $70 \%$ attendance to lectures to qualify to write examination policy is hardly implemented because students are prepared to bribe to pass. Inadequate learning leads to examination malpractices and other 'sharp' practices like bribery/sorting of lecturers. Inadequate learning also has serious implication for the performance of students and often leads to the production of 'half-baked or unbaked' graduates. Such graduates have low self-esteem as they lack the intellectual competitiveness required to thrive in the $21^{\text {st }}$ century job-market and workplace.

At the level of the lecturers, corruption is inimical to the essence of their calling and runs contrary to the oath to uphold the truth. Effects of corruption on teaching is grave, it also affects objectivity in grading of students scripts, leads to low self-esteem and morale because lecturers who collect money from students in order to award marks are hardly able to look at their students in the face. These lecturers also develop authoritarian relationship with students who do not give bribe. This type of relationship negates the mentored-mentor relationship that should exist between lecturers and students.

Among the non-academic staff, effects of corruption are also damaging. It affects the quality of service delivery in tertiary institutions. At the management level in higher education institution, corruption has serious implication for the execution of projects. Ogbonnaya (2009:86) observed that contractors handling major projects like administrative blocks and hostel buildings in universities are sometimes compelled by Ministry officials to offer bribes to them. Furthermore, he noted that the management of such institutions also receive bribes before contracts are awarded. Such acts result in unfinished projects. Other effects of corruption on post-secondary institutions include:

- Diversion, embezzlement and misappropriation of financial resources

- Wrong allocation of talents - hidden talents are killed, underdeveloped or misapplied

- Distorts values of young people - cynicism among young people. They feel it does not pay to be honest

- Blur lines between right and wrong, legal and illicit, good and evil

- Foreigners see graduates of Nigerian universities as very poor and second rate. This factor is responsible for many rich parents sending their children overseas to study at the detriment of the Nigerian economy as billions of Naira is lost as foreign exchange.

Since corruption is inimical to the progress and quality delivery of service in Nigerian higher institutions, it is expedient to curb it so that the goals of higher education will be effectively achieved.

\section{The Way Forward}

The following suggestions if properly implemented will assist in curbing corruption in tertiary institutions.

\subsection{Socialization of New Entrants (Lecturers, Non-Academic Staff and Students)}

Induction ceremonies including matriculation should aim at socializing the new comers into higher education. Mode of behaviour should be read out and copies of such documents be given to them at such ceremonies. This will portray the magnitude of seriousness attached to the issue of corruption in our institutions of higher studies. 


\subsection{Reorientation of Students and Lecturers}

Lectures, seminars and symposia should be instituted to reorient old lecturers and students on the consequences of corruption in higher education institutions specifically and the Nigerian society at large. At such fora, integrity role models or ambassadors should be invited to present public lectures. Deserving academic community members should be given rewards to encourage lecturers, administrators and students.

\subsection{Sensitization of Students, Lecturers and Administrators}

Functional ethics committees should be established in all institutions of higher studies. Women and men of high integrity should be appointed to be in charge of such committees. They should intermittently go to various units and departments within the institution to sensitize all staff and students on the consequence of corruption.

\subsection{Counselling}

Counselling units should be established in educational institutions of higher learning where such are not existent and strengthened where they exist. In these units, identified first-time offenders should be counselled and reintegrated into the institution. While appropriate punitive measures should be enforced on recalcitrant offenders. The counselling units should also prepare and circulate handbills stating the benefits of a corruption-free campus and effect of corruption on the administration of higher education institutions. Students, lecturers and administrators should be counselled to be content with what they have. Lack of contentment is responsible for some of the deviant practices found in our schools at this level.

Other measures to be used to halt the menace in our schools include:

- Recruitment of lecturers and promotion should be based on merit.

- Information on annual funds allocation to schools should be made public and proper monitoring should be instituted to guide against the diversion of such funds, misappropriation and embezzlement.

- Admission into institutions of higher studies should be strictly on merit.

- Monitoring teams for capital project execution should be established in all institutions of higher education and where they exist, should be strengthened to avert project abandonment, diversion of funds or outright embezzlement.

\section{Conclusion}

Corruption in institutions of higher education in Nigeria is widespread and it is assuming a near-crisis dimension. Administrators, students, lecturers and even some parents are indeed partakers in this menace. The consequences of this evil on the administration of Nigerian higher educational institutions are grave and needs to be curbed if the goals of our higher education institutions are to be achieved effectively. The demand to institute and implement portent strategies that will check the malady in our institutions of higher studies is urgent, so that Nigeria can take its position of pride among the nations of the world and rebuild confidence in our educational sector. A good measure of ethical reorientation is needed to restore the Nigerian institutions of higher studies back to its status at inception.

\section{References}

Constitution of the Federal Republic of Nigeria 1999 with Amendments 2011.

Federal Republic of Nigeria (2004). National Policy on Education (NPE), Yaba, Lagos: NERDC Press. Retrieved from http://www.uzochukwumike.hubpages.com Retrieved 10th May, 2015

Gurgur T., \& Shah A. (2000). Localization and Corruption: Panacea or Pandora's Box. Retrieved from http://www.ceade.imf.org/..../2000/...../gurgur:p.....

IMF (2000): Corruption Cost and mitigating strategies. Retrieved from https//www.....imf.org/external $/ \mathrm{pubs} / \mathrm{ft} / \mathrm{sdn} / \ldots . . . / \mathrm{sdn} 1605$

Independent Corrupt Practices and other related offences Commission, ICPC Act (2000). Abuja, Nigeria. Retrieved from; http.//icpc.gov.ng/wp-content/uploads/.../2012/.../corrupt-practices-Act-2010.pdf

Iyayi, F. (2010). Economic Reforms University Autonomy/Funding and Industrial Relations in Nigerian University System In Sustaining Effective Leadership in the Nigeria University System. Leadership Training Manual of Academic Staff Union of Universities (ASUU) National Secretariat Flat 2, Mellanby Hall University of Ibadan, 
Ibadan. Freedom Press and Publishers, Kaduna. Pp. 61-79.

Kurpe, S., Olive, R., \& Reeves R. (2011). Corruption and Education for all. Retrieved April 30, 2015 from www.slideshare.net/theimpact-corruption-has-on-education-for-all

Media Advocacy and Development ......(2013). Corruption: A case of Nigeria. Retrieved from http://www.antigraft.org//cc-case/corruption-casenigeria

Nigeria Masterweb Citizen News: Nigeria has the most outrageous Corruption - Leaders to blame. Retrieved from (http://nigeriamasterweb.com/blog/index.php)

Nkang, I.E. (2012). Basics of Educational Supervision. ISBN: 978-978-5064841.

Ogbonnaya, N.O. (2009). Social and Political Contexts of Educational Administration. Chuka Educational Publishers, Nsukka-Nigeria.

Ololube P. N (2016) Education Fund Misappropriation and Mismanagement and the Provision of Quality Higher Education in Nigeria. International Journal of Scientific Research in Education, 9(4), 333-349. Retrieved from www.ijsre.com/assets/vol.,-9(4)-Ololube.pdf

Olubunmi, S. (1995). Basic Moral Instructions for Primary Schools. Louis Gomes Nigeria

Oxford Advanced Learner's Dictionary of Current English. London University Press.

The Concise Oxford English Dictionary (Words Worth Reference). London. Oxford University, Press.

Torulagha, S.P (2013). The Corrosive Effects of Corruption on Nigerian Educational System. Retrieved from www.ganji.com/article6000/news7987.htm

Transparency International (TI) Corruption Perception Index (CPI), 2014. Retrieved from; www.transparency.org $>$.... $>$ Research $>$ Corruptionperceptionindex $>$ CPI2014 Corruption is threatening Economic growth of all

Uzochukwu M. (2015); Corruption in Nigeria: Review, Causes, Effects and Solutions. Publishers Lagos. Retrieved 24th May, $2015 . \quad$ From https://fbdglobalnews.wordpress.com/2015/.../Corruption-in-Nigeria-review-causes-eff.......

Uzochukwu, M.O. (2013). Challenges in Nigeria and Solutions on how to resolve them. Retrieved from; https://Soapboxie.com>worldpolitics 